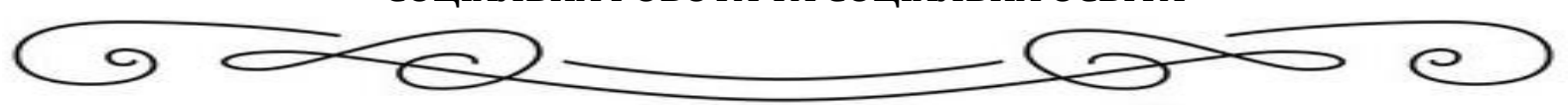

УДК 364.4-056.26:316.362

DOI: 10.31499/.3.2019.190399

\title{
СУЧАСНІ ПРОБЛЕМИ СІМЕЙ 3 ДІТЬМИ 3 ІНВАЛІДНІСТЮ В КОНТЕКСТІ СОЦІАЛЬНОЇ РОБОТИ
}

Підвальна Юлія, кандидат педагогічних наук, доцент кафедри соціальної педагогіки та соціальної роботи, Уманський державний педагогічний університет імені Павла Тичини.

ORCID: 0000-0002-4972-4232

E-mail: pidvalna_u@meta.ua

У статті розкрито найпоширеніші проблеми українських сімей, що виховують дітей 3 інвалідністю. Серед основних проблем в царині освіти дітей з інвалідністю виділяється: незручне територіальне розташування спеціалізованих закладів освіти; недостатній рівень освітньої і виховної роботи у специфічних закладах, нестачу дитячих творчих осередків; брак талановитих педагогів тощо. Акцентується увага на важливості комплексності в допомозі таким сім'ям. Підкреслено роль соціальної роботи у вирішенні проблем таких сімей, що мають дітей з інвалідністю.

Ключові слова: інвалідність, сім'я, діти з інвалідністю, соціальна допомога, спеціалізовані заклади освіти, реабілітація, соціальний працівник, рівноправність.

\section{CURRENT PROBLEMS \\ OF FAMILIES WITH CHILDREN WITH DISABILITIES IN THE CONTEXT OF SOCIAL WORK}

Pidvalna Juliia, PhD in Pedagogical Sciences, Associate Professor of the Department of Social Pedagogy and Social Work, Pavlo Tychyna Uman State Pedagogical University.

ORCID: 0000-0002-4972-4232

E-mail: pidvalna_u@meta.ua

The article describes the most common problems of Ukrainian families raising children with disabilities, summarizes subgroups of these problems and describes their manifestations in the current context. Emphasis is placed on the importance of comprehensiveness in helping such families. The role of social work in solving the problems of families with children with disabilities is emphasized.

The purpose of the article is to provide a theoretical analysis of the major problems faced by families with children with disabilities in contemporary Ukrainian society and the potential of social work to address these issues. The primary task of social work is social rehabilitation and social integration, that is, restoring the social status of families with children with disabilities.

Researchers note that in domestic practice, until recently, the peculiarities of the mental state of families with children with developmental disabilities were studied only as a concomitant aspect for the design of rehabilitation and educational work with the children themselves.

There is a wide variety of problems for such families - economic, legal, educational, informational, psychological, etc., but these problems can be reduced or even overcome by purposeful and methodical efforts aimed at different spheres of life. 


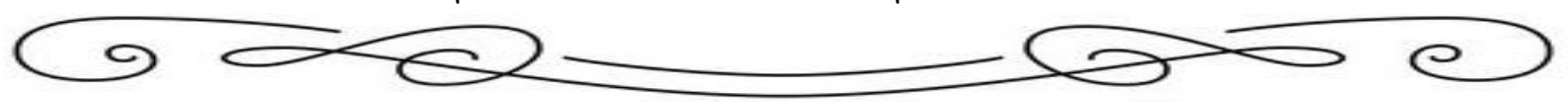

The problem of improving the social environment in which the family resides is urgent, so it is compulsory to further enhance synchronicity in moral education, especially for children and young people from both society and the family. In today's modern society, social work is one of the important tools for comprehensive assistance to families of children with special needs.

Keywords: disability, family, children with disabilities, social assistance, specialized educational institutions, rehabilitation, social worker, equality.

В сучасному світі захист дітей, сім'ї, забезпечення рівних можливостей та реалізації прав для всіх, особливо найвразливіших, груп населення набуває пріорітетності. В світлі цього підходу, актуального і для нашої країни, допомога сім'ям, що виховують дітей з інвалідністю.

Збільшення кількості дітей 3 інвалідністю $є$ великою проблемою для України. Воно зумовлене цілим рядом різноманітних екологічних, соціальних, економічних та інших чинників, що негативно впливають на загальне здоров'я населення. Крім того, відбувається розширення переліку захворювань та станів, які віднесено до інвалідності, а також розвиток медичних технологій, що дають шанс вижити багатьом дітям, які раніше помирали, проте, на жаль, це часто призводить до інвалідності. Серед порушень фізичного характеру, що спричиняють інвалідність дітей, виділяються вроджені аномалії, захворювання органів чуття, опорно-рухового апарату, органів дихання, ендокринної системи тощо. Дослідники звертають увагу на виключну роль сім'ї, як середовища для життя, розвитку і виховання дитини, особливо для дітей з функціональними порушеннями, адже для них родина є ще й першим і основним реабілітаційним середовищем. Водночас, не можна зводити вивчення родини лише до їі реабілітаційного та виховного потенціалу для дитини з особливими потребами.

Сім'я - це особлива соціальна система із специфічними зв'язками i стосунками, які вимагають цілісного підходу, адже зміна стану одного з членів сім'ї впливає на стосунки з іншими членами сім'ї і на відношення родини загалом із соціальним оточенням. Поява дитини з вадами розвитку помітно позначається майже на всіх сферах життєдіяльності родини, викликаючи потребу у підтримці і допомозі не лише для самої такої дитини, але й для родини загалом чи окремих її членів. Для успішної допомоги цим сім'ям важливо розуміти весь спектр труднощів, з якими вони стикаються. Варто також зазначити, що особливості стану розвитку сучасного українського суспільства вносять специфічні риси у проблеми сімей, що виховують дітей з інвалідністю.

Сучасні українські дослідники розглядають сім'ї, що мають дітей 3 особливими потребами, з позиції різних наук та підходів, зокрема можна виділити вичення особливостей психологічної сфери, психоемоційного клімату таких сімей (М. Карпа, Т. Комар, І. Лунгул), правового забезпечення соціального захисту дітей з вадами розвитку (Л. Шумна, В. Тарасенко, В. Кухарчук). У. О. Діково-Фаворської знаходимо соціологічний аналіз найрізноманітніших аспектів життя людей 3 особливими потребами, серед яких можна підкреслити питання самопочуття, самореалізації, освіти, проблем родин дітей з вадами розвитку. Труднощі родин, що мають неповносправних дітей 3 позицій соціальної та соціально-педагогічної роботи розкривають В.Білоус, Л.Саєнко. Соціальну допомогу та соціально- 


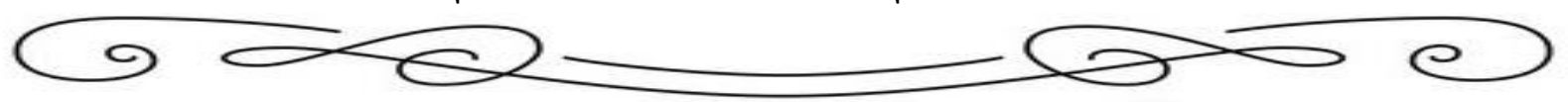

педагогічну і соціально-психологічну реабілітацію дітей з особливими потребами та їх родин розглянули в своїх дослідженнях А. Капська, О. Андрієнко, В. Тесленко, Л. Кобилянська, Н. Бастун, О. Безпалько.

Метою статті - $\epsilon$ теоретичний аналіз основних проблем, 3 якими стикаються родини, що мають дітей з інвалідністю в сучасному українському суспільстві та потенціалу соціальної роботи у вирішенні цих проблем.

Особою з інвалідністю $є$ особа зі стійким розладом функцій організму, що при взаємодії із зовнішнім середовищем може призводити до обмеження їі життєдіяльності, внаслідок чого держава зобов'язана створити умови для реалізації нею прав нарівні з іншими громадянами та забезпечити її соціальний захист. Інвалідність як міра втрати здоров'я визначається шляхом експертного обстеження в органах медико-соціальної експертизи центрального органу виконавчої влади, що забезпечує формування державної політики у сфері охорони здоров'я.

Поява дитини є, як правило, впливовою подією в житті родини, якщо ж дитина має обмежені можливості здоров'я, вона потребує підвищеної уваги, залучення різноманітних реабілітаційних ресурсів, особливого виховання. Зазвичай, умови, в яких опиняється сім'я з неповносправною дитиною, тим складніші, чим більші відхилення у розвитку дитини. Згуртованість, атмосфера взаємної підтримки, адекватне сприйняття труднощів допомагають родині подолати деякі складнощі, проте сучасний стан розвитку українського суспільства створює такі умови, в яких сім'ї, що мають дітей з особливими потребами зазнають багатьох труднощів та проблем, які, як правило, діють у комплексі і можуть підсилювати одна одну. Проблеми сучасних українських сімей із дітьми, що мають вади розвитку, можна класифікувати, розподіливши на своєрідні підгрупи, зокрема за різноманітними сферами життєдіяльності дитини 3 особливими потребами та родини загалом. Проте варто пам'ятати, що така класифікація носить в більшій мірі теоретичний та умовний характер, адже ці проблеми в реальності зазвичай дуже тісно переплетені, взаємопов'язані, можуть витікати одна з одної. Також слід зазначити, що в даному дослідженні увага зорієнтована лише на найбільш розповсюджених та найбільш частих для кожної сфери життя проблемах, тому що охопити все розмаїття складнощів в житті сімей, що виховують дітей з інвалідністю, надзвичайно важко через те, що в кожній такій сім'ї складається особлива ситуація, різні родини мають відмінний набір ресурсів різноманітного характеру для вирішення виникаючих проблем і можуть по-різному сприймати самі ці проблеми.

В першу чергу, поява у родині дитини з інвалідністю в більшості випадків має помітні наслідки для психологічного здоров'я сім'ї. Дослідники зазначають, що у вітчизняній практиці, донедавна особливості психічного стану родин, що мають дітей з вадами розвитку, вивчалися лише як супутній аспект для проєктування реабілітаційної та навчально-виховної роботи із самими дітьми. Психотравмуючий вплив факту інвалідності дитини на особистість їі родичів залишався без уваги. Проте, за ствердженням деяких дослідників: «ці дані характерні особливості родинних стосунків, виникнення у батьків таких дітей

Вип. 3, 2019

ISSN 2618-0715 


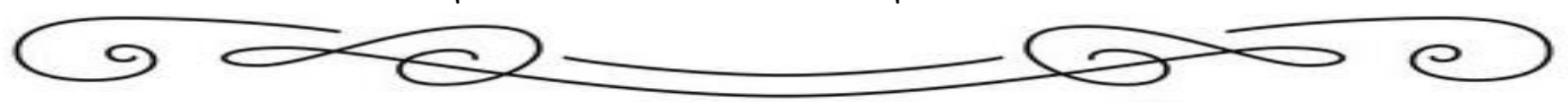

негативних рис характеру та особистісних порушень, поява різних соматичних захворювань, астенічних та вегетативних розладів, депресивної симптоматики тощо, - характеризують екстремальність життя зазначених родин» $[5,64]$.

Також серед негативних явищ психоемоційної сфери часто спостерігається низький потенційний рівень психологічного прийняття в сім'ї дитини 3 інвалідністю, емоційне відторгнення дитини, гіперопіка, надмірне акцентування уваги на вадах дитини тощо. Можуть порушуватися і підсистеми зв'язків: між батьком та матір'ю, батьками та іншими дітьми, іншими родичами. Нерідко ці проблеми ускладнюються низьким ступенем розвитку соціально-психологічних механізмів внутрішньосімейної взаємодії (порозуміння, взаємодопомоги, взаємного терпіння). Дуже важливою і поширеною проблемою, яка може проявлятися у будь-яких сферах життєдіяльності родини, є проблема нестачі інформації. Брак інформації може відчуватися батьками та родичами стосовно особливостей порушення здоров'я дитини, можливостей корекції та лікування, особливостей виховання, прав на соціальну допомогу, пільги, відповіних закладів освіти, наявних державних та громадських організацій тощо. Саме відсутність чи низька доступність інформації найчастіше унеможливлює своєчасну і відповідну допомогу дітям з інвалідністю та їх родинам.

Хоча в нашій країні і сформована певна законодавчо-нормативна база по захисту дітей з інвалідністю та їх сімей, дослідники виділяють проблеми правової сфери. Пов'язані вони не стільки з недоліками, що $є$ в самих правових документах, скільки із виконанням законів на належному рівні усіма ланками державного управління і фахівцями первинних структур [2]. Також часто постає проблема незнання родичами дитини з особливими потребами всіх прав, гарантованих законодавством, орієнтації у розмаїтті нормативно-правових документів.

Серед основних проблем в царині освіти дітей 3 інвалідністю можна виділити: незручне територіальне розташування спеціалізованих закладів освіти; недостатній рівень освітньої і виховної роботи у специфічних закладах, нестачу дитячих творчих осередків; брак талановитих педагогів тощо [1]. Поширення в нашій країні методу навчання дітей з інвалідністю у загальноосвітніх школах викликає цілу низку проблем, що включають і труднощі адаптації таких дітей до середовища загальноосвітньої школи, і непристосованість самих навчальних закладів до їх потреб (відсутність обладнання, кваліфікованих спеціалістів тощо), i сприйняття нетипових дітей оточенням. Важливим аспектом $\epsilon$ також гарантована державою для дітей із порушеннями здоров'я, але зі збереженим інтелектом, можливість продовження освіти у вищих та професійно-технічних навчальних закладах, працевлаштування. Ці права поки що не забезпечуються потрібним чином.

В умовах економічної нестабільності залишається проблемою низька матеріальна забезпеченість сімей, що виховують дітей 3 вадами розвитку, труднощі в реалізації гарантованих державою пільг. Як зазначають дослідники [2; 4], економічне становище сім'ї, яке і без того часто $є$ невисоким, ускладнюється хворобою дитини, яка потребує догляду (а це нерідко унеможливлює заробіток матері), дорогого лікування, різних технічних засобів тощо. 


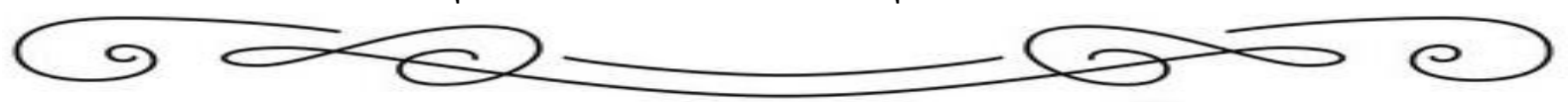

Не подолані в нашій країні і труднощі соціально-медичного характеру. Це найбільше виражається в недостатньому розвитку та доступності технологій ранньої діагностики, корекції, реабілітації, прогнозування медичних наслідків інвалідності, в невисокому рівні забезпечення безкоштовними медичними послугами та ліками, у нестачі кваліфікованих спеціалістів.

На жаль, залишаються надзвичайно актуальними для України питання інтеграції людей з обмеженими можливостями в суспільство. Поширеним є явище несприйняття таких людей повноцінними членами соціуму. Як слушно зазначає Л. Саєнко: «головною проблемою, яка потребує негайного вирішення, $є$ подолання соціальної ізоляції інвалідів, обмеженості їх спілкування, організація їх дозвілля, навчання, пошуку можливого заробітку» $[4,79]$. Повноцінній соціальній інтеграції та самореалізації осіб з порушеннями здоров'я заважає упередженість та стереотипність в ставленні до них з боку багатьох здорових людей. Типовим для українського суспільства $\epsilon$ перенесення багатьох негативних стереотипів і на родичів людини 3 інвалідністю. Крім того в нашій країні залишаються неподоланими суто фізичні та технологічні перепони у доступі людей 3 обмеженими можливостями здоров'я до різноманітних об'єктів, споруд, проблеми транспортного забезпечення та доступу до інформації.

Як бачимо, коло проблем, з якими може стикатися сучасна українська родина, що виховує неповносправну дитину, досить широке та багатоманітне. Зазвичай, ситуація, в якій опиняється така родина, являє собою комплекс труднощів різного характеру, що тісно переплітаються, а нерідко і взаємно обумовлюються.

Саме тому виникає необхідність у комплексній, багатоаспектній допомозі, яка потребує залучення різних спеціалістів, в тому числі і спеціалістів з соціальної роботи. Саме соціальний працівник, який повинен мати певний об'єм знань і практичних навичок медичної, юридичної, психолого-педагогічної, фінансовоекономічної і соціально-побутової допомоги, може здійснювати багатоаспектну підтримку сімей, що мають нетипових дітей.

Соціальна робота має багате технологічне підгрунтя для допомоги дітям 3 особливими потребами та їх родинам: технології соціальної реабілітації та адаптації, технології корекційної та терапевтичної роботи, технології соціального забезпечення та соціального обслуговування, технології консультування тощо.

Соціальна робота може охоплювати різні рівні: від індивідуальної роботи 3 вирішення проблем конкретного індивіда до роботи з групою людей чи цілою громадою, а деякі проблеми можуть вирішуватися на рівні суспільства загалом. Головною метою в соціальній роботі з сім'єю дитини 3 інвалідністю є допомога родині у забезпеченні оптимальних умов для виховання і розвитку хворої дитини, створенні сприятливого реабілітаційного середовища, а також допомога у збереженні повноцінного функціонування сім'ї як цілісної системи та всіх їі членів.

В процесі реабілітації дитини з вадами розвитку, що здійснюється цілою командою різних фахівців (медичних та соціальних працівників, психологів, 


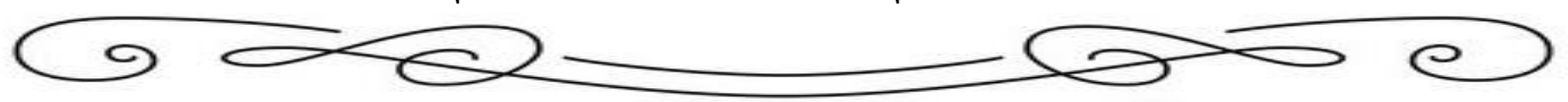

педагогів тощо), соціальний працівник виконує важливі функції, наприклад: комплексного вивчення сім'ї дитини; розкриття ресурсів самої родини та залучення зовнішніх ресурсів; інформування та консультації членів родини 3 багатьох питань та допомоги в їх контакті з різними фахівцями; координації роботи самої команди.

Першочерговим завданням соціальної роботи $є$ соціальна реабілітація та соціальна інтеграція, тобто відновлення соціального статусу сімей, що мають дітей з інвалідністю. Л. Кобилянська наголошує, що соціальна підтримка таких сімей - широкий спектр довгострокових заходів комплексного (медичного, правового, економічного, психолого-педагогічного) характеру, які спрямовані на розширення контактів сім'ї, подолання соціального виключення, залучення до суспільного життя; надання адекватної інформації про перспективи розвитку дитини та її специфічні потреби; сприяння в організації комплексної діагностики і якомога ранішого початку освітнього процесу; надання повноцінної інформації про державну та громадську підтримку, можливі пільги; налагодження сімейного мікроклімату; організація психологічної підтримки батьків та інших членів сім'ї; організація правової підтримки сім'ї, захист її законних прав та інтересів [3].

Отже, можна сказати, що родини, що мають дітей 3 інвалідністю, в сучасному українському суспільстві захищені недостатньо. Існує цілий спектр найрізноманітніших проблем таких родин - економічних, правових, освітянських, інформаційних, психологічних тощо, проте ці проблеми можуть бути зменшені чи взагалі подолані цілеспрямованими та методичними зусиллями, направленими на різні сфери життєдіяльності.

Актуальним залишається проблема вдосконалення соціального середовища, в якому перебуває сім'я, тому конче необхідним $€$ подальше нарощування синхронності у моральному вихованні, особливо дітей та молоді з боку як суспільства, так і сім'ї. В сучасному суспільстві соціальна робота $\epsilon$ одним із важливих інструментів комплексної допомоги родинам дітей 3 особливими потребами. Крім роботи із самими родинами, соціальні працівники можуть вирішувати проблеми сімей, що виховують нетипових дітей, на рівні громад чи суспільства загалом. Як відомо, 3 поступовим розвитком громадянського суспільства держава втрачає свою монополію на здійснення соціальної політики по відношенню до сім'ї, її розмивають громадські, благодійні організації та фонди за рахунок як безпосереднього, так і опосередкованого впливу на різні категорії населення і типи сімей.

Тому актуальним залишається необхідність створення різноманітних організацій дітей та молоді 3 вадами розвитку та їх родичів, боротьба 3 упередженістю та стереотипами з боку суспільства, донесення інтересів сімей із неповносправними дітьми до діячів влади, стимулювання доброчинної допомоги таким сім'ям тощо. Розвиток в Україні багатьох перспективних напрямів соціальних послуг стане запорукою покращення життя сімей, що виховують дітей з обмеженими фізичними можливостями. 


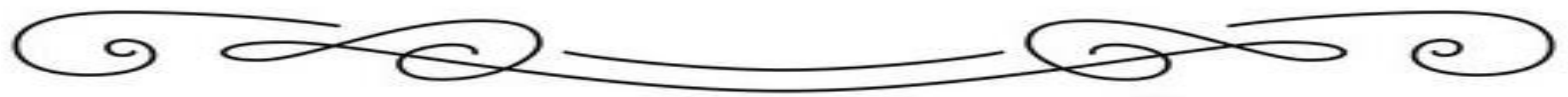

\section{СПИСОК ВИКОРИСТАНИХ ДЖЕРЕЛ}

1. Білоус В.М. Соціально-педагогічні умови реалізації моделі комплексної медикопсихологопедагогічної реабілітації дітей-інвалідів у Луганській області. Ціннісні пріоритети освіти у XXI столітті: інноваційний розвиток освітніх систем. Луганськ, 2007. Ч. 3. С. 235-238.

2. Дікова-Фаворська О. М. Специфічні групи осіб з обмеженими можливостями здоров'я у фокусі соціології: монографія. Житомир: Полісся, 2009. 488 с.

3. Кобилянська Л. І. Взаємодія соціального гувернера 3 сім'єю, що виховує дитину-інваліда. Теоретико-методичні проблеми виховання дітей та учнівської молоді. Київ, 2002. Кн. 2. C. 57-62.

4. Саєнко Л. І. Проблеми сімей, які виховують дитину-інваліда. Людина і суспільство: основні тенденції розвитку і фактори трансформації у філософському, соціальному та психологічному вимірі. Чернігів, 2006. С. 70-80.

5. Служби раннього втручання в Україні: шлях до інтеграції / за наук. ред. Н.А. Бастун. Київ: Леста, 2005. 184 с.

\section{REFERENCES}

1. Bilous, V. M. (2007). Sotsialno-pedahohichni umovy realizatsii modeli kompleksnoi medykopsykholohopedahohichnoi reabilitatsii ditei-invalidiv u Luhanskii oblasti. Tsinnisni priorytety osvity $u$ XXI stolitti: innovatsiinyi rozvytok osvitnikh system. Luhansk, Ch. 3. 235-238 [in Ukrainian].

2. Dikova-Favorska, O. M. (2009). Spetsyfichni hrupy osib z obmezhenymy mozhlyvostiamy zdorovia u fokusi sotsiolohii. Zhytomyr: Polissia [in Ukrainian].

3. Kobylianska, L. I. (2002). Vzaiemodiia sotsialnoho huvernera z simieiu, shcho vykhovuie dytynuinvalida. Teoretyko-metodychni problemy vykhovannia ditei ta uchnivskoi molodi. Kyiv, Kn. 2, 57-62 [in Ukrainian].

4. Saienko, L. I. (2006). Problemy simei, yaki vykhovuiut dytynu-invalida. Liudyna i suspilstvo: osnovni tendentsii rozvytku i faktory transformatsii u filosofskomu, sotsialnomu ta psykholohichnomu vymiri. Chernihiv, 70-80 [in Ukrainian].

5. Sluzhby rannioho vtruchannia v Ukraini: shliakh do intehratsii. (2005). N. A. Bastun (Ed.). Kyiv: Lesta [in Ukrainian]. 